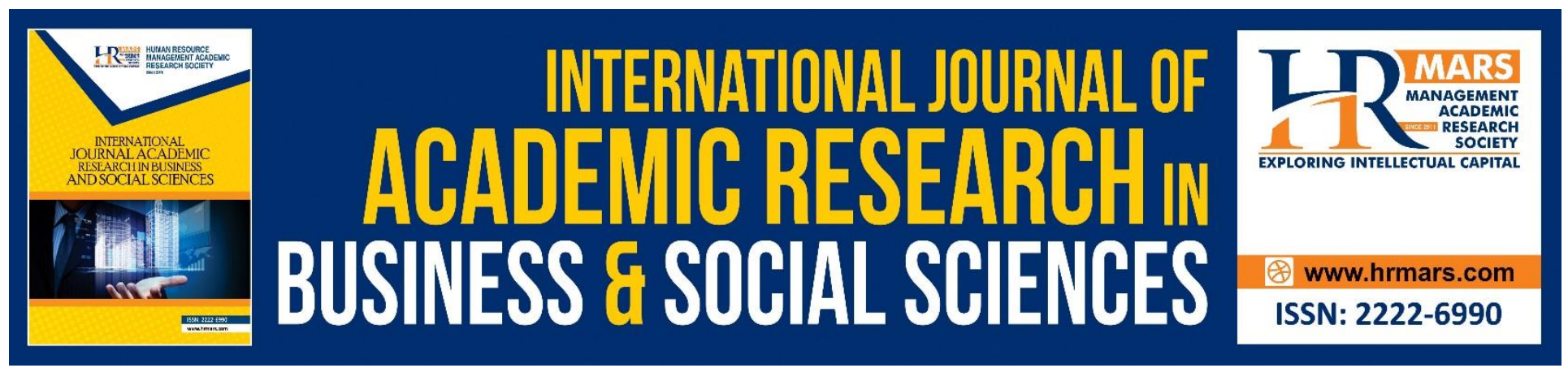

\title{
Factors that Influence Self-Perceived Academic Cheating: An Empirical Evidence of Business Students
}

Norashikin Hussein, Nor Azian Abdul Rahman, Syezreen Dalina Rusdi, Muhamad Khalil Omar and Zarith Zulaikha Abd Aziz

To Link this Article: http://dx.doi.org/10.6007/IJARBSS/v8-i11/4952

DOI: $10.6007 /$ IJARBSS/v8-i11/4952

Received: 22 Sept 2018, Revised: 19 Oct 2018, Accepted: 06 Nov 2018

Published Online: 16 Nov 2018

In-Text Citation: (Hussein, Rahman, Rusdi, Omar, \& Aziz, 2018)

To Cite this Article: Hussein, N., Rahman, N. A. A., Rusdi, S. D., Omar, M. K., \& Aziz, Z. Z. A. (2018). Factors that Influence Self-Perceived Academic Cheating: An Empirical Evidence of Business Students. International Journal of Academic Research in Business and Social Sciences, 8(11), 758-767.

Copyright: (C) 2018 The Author(s)

Published by Human Resource Management Academic Research Society (www.hrmars.com)

This article is published under the Creative Commons Attribution (CC BY 4.0) license. Anyone may reproduce, distribute, translate and create derivative works of this article (for both commercial and non-commercial purposes), subject to full attribution to the original publication and authors. The full terms of this license may be seen

at: http://creativecommons.org/licences/by/4.0/legalcode

Vol. 8, No. 11, 2018, Pg. 758 - 767

http://hrmars.com/index.php/pages/detail/IJARBSS

JOURNAL HOMEPAGE

Full Terms \& Conditions of access and use can be found at http://hrmars.com/index.php/pages/detail/publication-ethics 


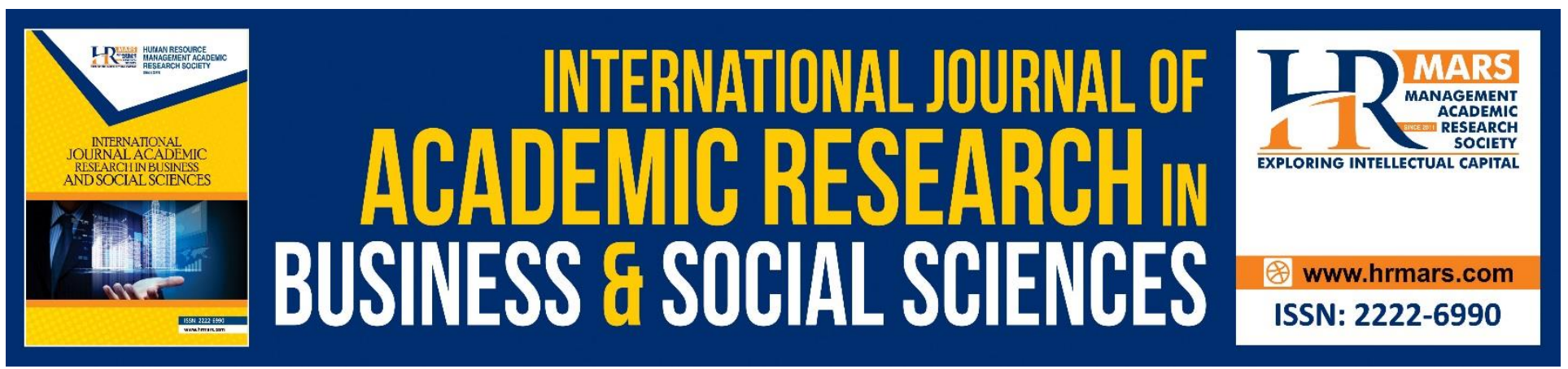

\title{
Factors that Influence Self-Perceived Academic Cheating: An Empirical Evidence of Business Students
}

\author{
Norashikin Hussein, Nor Azian Abdul Rahman, Syezreen Dalina \\ Rusdi, Muhamad Khalil Omar and Zarith Zulaikha Abd Aziz \\ Faculty of Business and Management, University Teknologi Mara, Puncak Alam \\ Malaysia
}

\begin{abstract}
For decades, academic cheating is one of the imperative topics that have been uncovered in the field of education. In fact, recent statistics on academic cheating among students in higher education institutions are reported to be on the rise. The main purpose of this study is to examine factors contributing to academic cheating behaviors among business students in a public university, in Malaysia. This quantitative research is intended to determine the relationships of internet facilities, lack of competencies, negative attitudes and pressures towards academic cheating. A total of 364 tertiary students were involved in this study. Descriptive analysis, Pearson correlation and multiple regressions were used to analyze the data collected and to test hypotheses. The results found that negative attitude was the most significant predictor of academic cheating. Therefore, it is hoped that the results of this study will enlighten the educators and higher education institutions to better understand the reasons behind the occurrence of academic cheating activities among undergraduate students.
\end{abstract}

Keywords: Test Cheating, Assignment Cheating, Internet Facilities, Lack Of Competency, Negative Attitude, Pressure

\section{Introduction}

Over the years, academic cheating continues to be a pervasive issue that has always been a threat to academic honesty and social values. The subject of academic cheating has attracted the attention of not only academics but also public communities. Recent studies have proven that the issues of academic cheating among undergraduates have increased along the years. For example, 76 percent of the students confessed to having involved in academic cheating (Jeergal et al., 2015). In Malaysia, 65.3 percent of the students confessed that they have cheated in final examinations, mid semester examination or class assignments (Ismail \& Yussof, 2016). It is evident that this phenomenon is alarming. The habit of cheating go beyond the academic world, those who commit such fraud will eventually continue their cheating ways when they join the workforce. 
Previous studies conducted on academic cheating have looked into various perspectives. Some studies focused on the relationship between motivation and cheating behavior, some focused more on the relationship between socio-demographic factors and cheating behavior (e.g., Jung-In, Jun and Shane (2015)). Others (e.g., Donse and Van De Goep (2013)) have carried out studies to determine what causes students to cheat. However, studies on factors that influence students to cheat are still scarce and there is a need to explore factors that influence academic cheating (Donse \& Van De Goep, 2013), specifically in the context of Malaysia. Thus, the study aims to identify factors that lead to academic cheating among business students.

\section{Literature Review}

Academic cheating is an immoral way of achieving a goal in the field of academic (Kalhori, 2014). In the context of this study, academic cheating is generally composed of two different forms, cheating in tests and cheating in assignments. Test cheating is defined as an act of deception using unpermitted items and information during examinations in order to gain unfair advantage over others (Muchai, 2014). Meanwhile, assignment cheating is an act that deceives, misleads or fools the lecturer into thinking that the assignment submitted by the student was a student's own work (Davis, Drinan \& Bertram-Gallant, 2009).

Technological factors such as the use of internet for assignment completion has increased the possibility of academic misconduct (Hosny \& Shameem, 2014). In fact, the growth of technology through social media has provided electronic storage opportunities as well as platforms for sharing and archiving exams or answers for anyone who searches for it (Smith, Ghazali \& Noor Minhad, 2007). Another study discovered that students actively cheat on assignments rather than on examinations (King \& Case, 2014). Additionally, the internet which has been used by students in their personal lives has helped them to get the information needed for assignments (Anitsal, Anitsal \& Elmore, 2009). Hutton (2006) also stated that the easy access of the internet has increased the opportunity for students to share work in unethical ways. Therefore, it is hypothesized that:

\section{H1: There is a positive significant relationship between internet facilities and academic cheating.}

$\mathrm{H} 1(\mathrm{a})$ : There is a positive significant relationship between internet facilities and test cheating.

$\mathrm{H} 1(\mathrm{~b})$ : There is a positive significant relationship between internet facilities and assignment cheating.

Lack of competency is related to the difficulties encountered by students both in understanding articles and in constructing sentences in English (Smith et al., 2007). According to Kalhori (2014), students cheat because of some extrinsic factors such as maintaining grades and 'successful image' to themselves or to their friends and lacking self-efficacy to complete complex tasks. These deficiencies encourage students to copy assignments from peers without the authors' consent. David (2015) added that students with high self-esteem and mastery feeling cheat less. In fact, high selfesteem was found to be negatively associated with cheating behaviors. Another study proved that 
INTERNATIONAL JOURNAL OF ACADEMIC RESEARCH IN BUSINESS AND SOCIAL SCIENCES Vol. 8, No. 11, Nov, 2018, E-ISSN: 2222-6990 (C) 2018 HRMARS

self-efficacy was inversely related with academic cheating (Nora \& Zhang, 2010). Hence, it is hypothesized that:

H2: There is a positive significant relationship between lack of competency and academic cheating.

$\mathrm{H} 2(\mathrm{a})$ : There is a positive significant relationship between lack of competency and test cheating.

$\mathrm{H} 2(\mathrm{~b})$ : There is a positive significant relationship between lack of competency and assignment cheating.

Negative attitudes towards learning include lack of interest and laziness to study (Smith et al., 2007). Bagraim, Goodman and Pulker (2014) highlighted that favorable attitude towards academic misconduct is significantly related to academic cheating. It is also supported by Bolin (2004) who stated that academic dishonesty has been influenced by self-control, perceived opportunity and attitude towards academic. Positive or negative attitude may influence the involvement in academic dishonesty because cheating is seen as an alternative to hard work (Smith et al., 2007). Mustapha, Hussin, Siraj and Darusalam (2016) also reported that attitude has become a significant predictor in predicting academic cheating among students. Therefore, it is hypothesized that:

\section{H3: There is a positive significant relationship between negative attitude and academic cheating}

$\mathrm{H} 3(\mathrm{a})$ : There is a relationship between negative attitude and test cheating.

$\mathrm{H} 3$ (b): There is a relationship between negative attitude and assignment cheating

Another factor identified for academic cheating is pressure from parents, teachers and peers (Sarita \& Dahiya, 2015). The type of pressure examined in this study is the individual's perceived pressure (such as time and task pressure). As stated by Ellahi, Mushtaq and Khan (2013), some students commit cheating due to the pressure of meeting deadlines which usually arises at the end of semester when they have to submit many assignments, projects and presentations. Ma, McCabe and Liu (2013) postulated that a student who experiences high pressure is more likely to commit academic cheating as a coping mechanism. On the other hand, Lin and Wen (2007) found that students who are highly pressured by family, task commitment or time factors are more likely to commit plagiarism but not academic cheating. Similarly, there was no evidence found to support that individual perceived pressure was related to the increase in the incidence of academic dishonesty (Smith et al., 2007). Hence, it is hypothesized that:

H4: There is a positive significant relationship between pressure and academic cheating.

$\mathrm{H} 4(\mathrm{a})$ : There is a relationship between pressure and test cheating.

$\mathrm{H} 4$ (b): There is a relationship between pressure and assignment cheating. 
INTERNATIONAL JOURNAL OF ACADEMIC RESEARCH IN BUSINESS AND SOCIAL SCIENCES

Vol. 8, No. 11, Nov, 2018, E-ISSN: 2222-6990 @ 2018 HRMARS

The proposed Conceptual Framework is in Figure 1.1

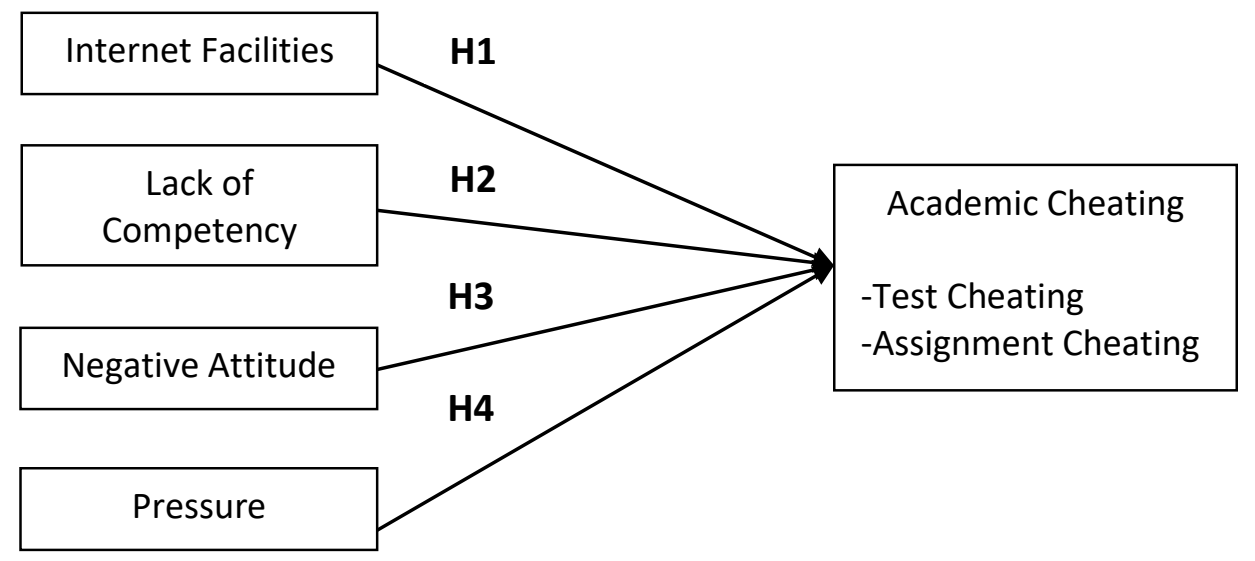

\section{Methodology}

This study used quantitative research design by using purposive sampling method, 364 students from a business faculty of public university in Malaysia were selected as the sample of the study. The survey was administered personally by the researchers as a means to collect data. For items on test and assignment cheating, four and three items were adapted from Ma et al. (2013) respectively. Meanwhile, items for internet facilities ( 3 items), lack of competency ( 6 items), negative attitude (5 items) and pressure (4 items) were adopted from Smith et al. (2007). All items were rated using 5point Likert scale. All data were analyzed using Statistical Package for the Social Sciences (SPSS). Statistical analyses such as descriptive analysis, reliability analysis, correlational analysis and multiple regression analysis were used in the study.

\section{Results and Discussion}

From the survey it was found that from the total number of 364 respondents, 26.4 percent were male and 73.6 percent were female. The majority of the respondents ( 89.6 percent) involved in the study were consisted of Malay ethnicity. 68.2 percent of the respondents were final year students and 54.7 percent of the total respondents had CGPA scores ranging from 3.01 to 3.50. The findings also implied that 14.8 percent of the respondents have part time job. 30.8 percent of the respondents responded that they were actively involved in co-curriculum activities, with 28.3 percent responded that they participated in at least one to five co-curriculum activities in a semester. Out of the 364 respondents, 17.6 percent of the respondents received scholarships while 15.4 percent operated an online business.

Table 1 shows the internal consistency of variables used in the study. All variables were found to be acceptable and reliable based on their Cronbach alpha values which ranged from 0.76 to 0.89 . Among the independent variables, internet facilities show the highest mean of $3.74(S D=0.79)$, followed by 
INTERNATIONAL JOURNAL OF ACADEMIC RESEARCH IN BUSINESS AND SOCIAL SCIENCES

Vol. 8, No. 11, Nov, 2018, E-ISSN: 2222-6990 @ 2018 HRMARS

pressure $(\mu=3.21, \mathrm{SD}=0.81)$, lack of competency $(\mu=2.77, \mathrm{SD}=0.76)$, and negative attitude $(\mu=2.21$, $\mathrm{SD}=0.76)$. For dependent variables, assignment cheating has a mean of $2.31(\mathrm{SD}=0.86)$ while, test cheating show the mean of $1.88(\mathrm{SD}=0.86)$.

Table 1: Reliability and Descriptive Analysis

\begin{tabular}{lccccc}
\hline Variables & $\begin{array}{c}\text { No. of } \\
\text { Items }\end{array}$ & $\begin{array}{c}\text { Cronbach } \\
\text { Alpha }\end{array}$ & $\begin{array}{l}\text { Items } \\
\text { Dropped }\end{array}$ & $\begin{array}{c}\text { Mean } \\
\text { Standard } \\
\text { Deviation }\end{array}$ \\
\hline Test Cheating & 4 & 0.89 & - & 1.88 & 0.86 \\
Assignment Cheating & 3 & 0.78 & - & 2.31 & 0.86 \\
Internet Facilities & 3 & 0.76 & - & 3.74 & 0.79 \\
Lack of Competency & 6 & 0.83 & - & 2.77 & 0.76 \\
Negative Attitude & 5 & 0.89 & - & 2.21 & 0.90 \\
Pressure & 4 & 0.77 & - & 3.21 & 0.81 \\
\hline
\end{tabular}

Pearson correlation analysis was conducted to examine the associations between variables in the study. In this correlational analysis, the direction, significance and strength were identified. Based on the results, only lack of competency $(r=0.27, p<0.01)$ and negative attitude $(r=0.42, p<0.01)$ have a significant correlation with test cheating. On the other hand, all independent variables have reported a positive significant relationship with assignment cheating. Specifically, Table 2 indicates that all correlation values ranges from 0.14 to 0.38 . The results shows that there was a positively small correlation between internet facilities and assignment cheating $(r=0.21, p<0.01)$, between lack of competency and assignment cheating $(r=0.29, p<0.01)$, and between pressure and assignment cheating $(r=0.14, p<0.01)$. It was also found that there was a positive moderate association between negative attitude and assignment cheating $(r=0.38, p<0.01)$.

Table 2: Pearson Correlation Analysis

\begin{tabular}{|c|c|c|c|c|c|c|}
\hline & $\begin{array}{l}\text { Test } \\
\text { Cheating }\end{array}$ & $\begin{array}{l}\text { Assignment } \\
\text { Cheating }\end{array}$ & $\begin{array}{l}\text { Internet } \\
\text { Facilities }\end{array}$ & $\begin{array}{l}\text { Lack of } \\
\text { Competency }\end{array}$ & $\begin{array}{l}\text { Negative } \\
\text { Attitude }\end{array}$ & Pressure \\
\hline Test Cheating & 1 & & & & & \\
\hline Assignment Cheating & $0.63^{* *}$ & 1 & & & & \\
\hline Internet Facilities & 0.05 & $0.21^{* *}$ & 1 & & & \\
\hline Lack of Competency & $0.27^{* *}$ & $0.29^{* *}$ & $0.18^{* *}$ & 1 & & \\
\hline Negative Attitude & $0.42^{* *}$ & $0.38^{* *}$ & $0.13^{*}$ & $0.53^{* *}$ & 1 & \\
\hline Pressure & 0.10 & $0.14^{* *}$ & $0.28^{* *}$ & $0.35^{* *}$ & $0.31^{* *}$ & 1 \\
\hline
\end{tabular}

Note:

**Correlation is significant at the 0.01 level (2-tailed)

* Correlation is significant at the 0.05 level (2-tailed).

Table 3 below summarizes the result of multiple regression analysis. The $\mathrm{R}^{2}$ value for test cheating as the dependent variable is 0.18 . Thus, it suggests that all independent variables such as internet 
facilities, lack of competency, negative attitude and pressure explained the 18.1 percent variance of test cheating. Meanwhile, the $\mathrm{R}^{2}$ value for assignment cheating as the dependent variable is 0.42 . Therefore, all independent variables which are internet facilities, lack of competency, negative attitude and pressure explained the 42.2 percent of variance in assignment cheating. Based on the $F$ test, test cheating and assignment cheating were significant at the 0.01 level. It was found that only negative attitude has a positive and significant effect on test cheating $(\beta=0.40, p<0.01)$, while, internet facilities, lack of competency, and pressure have no significant effect on test cheating. On the other hand, only two independent variables were found to be linked to assignment cheating. Negative attitude was found to be the highest contributor to assignment cheating $(\beta=0.316, p<0.01)$. It was also found that internet facilities have a positive and significant effect on test cheating ( $\beta=$ $0.158, p<0.05$ ) while lack of competency and pressure has no significant effect on assignment cheating.

Table 3: Multiple Regression Analysis

\begin{tabular}{lll}
\hline $\begin{array}{l}\text { Independent } \\
\text { Variables }\end{array}$ & $\begin{array}{l}\text { Dependent Variable }(\boldsymbol{\beta}) \\
\text { Test Cheating }\end{array}$ & $\begin{array}{l}\text { Dependent Variable }(\boldsymbol{\beta}) \\
\text { Assignment Cheating }\end{array}$ \\
\hline Internet Facilities & -0.01 & $0.16^{*}$ \\
Lack of Competency & 0.07 & 0.11 \\
Negative Attitude & $0.40^{* *}$ & $0.32^{* *}$ \\
Pressure & -0.05 & -0.40 \\
\hline F Value & $19.48^{* *}$ & $19.44^{* *}$ \\
$\mathrm{R}^{2}$ & 0.18 & 0.42 \\
Adjusted $\mathrm{R}^{2}$ & 0.17 & 0.18 \\
\hline Note. ${ }^{*} \mathrm{p}<0.05,{ }^{* *} \mathrm{p}<0.01$ &
\end{tabular}

Overall, it was found that negative attitude has the most significant effect on both test cheating and assignment cheating. This result is similar to Bagraim et al. (2014) who revealed that a favorable attitude towards academic dishonesty was found to be a significant predictor of academic cheating. Similarly, the findings of the study is similar to a study by Mustapha et al. (2016) who found that attitude is the best predictor in predicting cheating intention among Malaysian students. Hence, H3 is supported.

Internet facilities were discovered to have the second highest influence on assignment cheating. According to King and Case (2014), students actively cheat on term papers or homework rather than on real examination. In this case, students may find it difficult to browse internet or access Google in examination hall. However, the growth of website technology has contributed to assignment cheating (Smith et al., 2007). Thus, only H1 (b) was supported.

Contrary to previous findings, this study did not find any relationship between lack of competency and test cheating. In addition, there was no relationship between lack of competency and assignment cheating. According to Nora and Zhang (2010), there was an inverse relationship between selfefficacy and academic cheating. Lack of competency however, was not related with both test cheating and assignment cheating. This may due to the risk of getting caught in the act which would 
expose them to shame (Błachnio \& Weremko, 2011). The researchers also added that it also possible that student with high self-efficacy commit academic cheating, whereas student with low self efficacy may adopt the attitude of risk avoidance. Hence, $\mathrm{H} 2$ was not supported.

Based on the results, there was no relationship found between pressure and academic cheating. The findings is in contrast with Sarita and Dahiya (2015) who predicts that pressure from teachers, parents and peers may contribute to academic cheating. Similarly, Lin and Wen (2007) revealed that students who are highly pressured by family, task commitment or time factors are more likely to self-report plagiarism activities but not on academic cheating. However, in this case, no evidence was found to support the idea of self-imposed pressure with the incidence of academic cheating. In fact, Smith et al. (2007) posited that no evidence was found to support the suggestion that pressure had increased the incidence of academic dishonesty. Therefore, $\mathrm{H} 4$ was not supported.

This study also suggests on additional future research directions. Firstly, the results obtained in this study were based purely on business students of one public university in Malaysia. Hence, future research should involve other faculties and other public universities in Malaysia. Secondly, it is suggested that future study to be conducted using other types of academic dishonesty such as plagiarism in order to get better understanding of the actual concept of academic dishonesty. Finally, future study should also include moderating or mediating variables in fully understanding the academic dishonesty model.

\section{Conclusion}

Academic cheating is a 'disease' that should be taken seriously to curb the behaviour of academic dishonesty. It can be challenging to overcome the behaviour of academic dishonesty but an ongoing effort must be undertaken to lessen its occurrence. This particular study has shown that negative attitude influences both test and assignment cheating. Therefore, the institutions of higher learning should organize programmes to promote academic integrity and inculcating an ethical behaviour amongst tertiary students. Students should also be made aware on the negative implications they will receive if they are found to be involved in the behaviour of academic dishonesty. Institutions of higher learning should also implement a clear and stricter policy on the act of academic dishonesty.

\section{Acknowledgement}

This research is funded by RAGS 5/3 (75/2015), administered by the Research Management Centre (RMC) of Universiti Teknologi MARA, Shah Alam, Selangor, Malaysia.

\section{Corresponding Author}

Norashikin Hussein, Faculty of Business and Management, University Teknologi Mara, Puncak Alam, Malaysia

\section{References}

Anitsal, I. Anitsal, M. \& Elmore, R. (2009). Academic dishonesty and intention to cheat : A model on active versus passive academic dishonesty as perceived by. 13(2): 17-27. 
INTERNATIONAL JOURNAL OF ACADEMIC RESEARCH IN BUSINESS AND SOCIAL SCIENCES

Vol. 8, No. 11, Nov, 2018, E-ISSN: 2222-6990 @ 2018 HRMARS

Bagraim, J., Goodman, S. \& Pulker, S. (2014). Understanding dishonest academic behaviour amongst business students - The business leaders of the future, Industry and Higher Education, 28(5): 331-340.

Błachnio, A. \& Weremko, M. (2011). Academic cheating is contagious: The influence of the presence of others on honesty. A Study Report, 1(1): 14-19.

Bolin, A. U. (2004). Self-control, perceived opportunity, and attitudes as predictors of academic dishonesty. The Journal of Psychology, 138(2): 101-114.

David, L. T. (2015). Academic cheating in college students: Relations among personal values, selfesteem and mastery. Procedia - Social and Behavioral Sciences, 187: 88-92.

Davis, S., Drinan, P. \& Bertram-Gallant, T. (2009). Cheating in school: What we know and what we can do. West Sussex: John Wiley \& Sons, Ltd.

Donse, L. \& Van De. Goep, I. H. (2013). Academic dishonesty among college students : Predictors and interventions, Social Cosmos, 10(1): 40-50.

Ellahi, A., Mushtaq, R. \& Khan, M. B. (2013). Multi campus investigation of academic dishonesty in higher education of Pakistan. International Journal of Educational Management, 27(6): 647-666.

Hosny, M. \& Shameem, F. (2014). Attitude of Students Towards Cheating and Plagiarism. University Case Study.

Hutton, P. (2006). Understanding student cheating and what educators can do about it. College Teaching, 54(1): 171-172.

Ismail, S. \& Yussof, S. H. (2016). Cheating behaviour among accounting students: Some Malaysian evidence. Accounting Research Journal Iss Accounting Research Journal, 29(1): 20-33.

Jeergal, P. A., Surekha, R., Sharma, P., Anila, K., Jeergal, V. A. \& Rani, T. (2015). Prevalence, perception and attitude of dental students towards academic dishonesty and ways to overcome cheating behaviors. Journal of Advanced Clinical \& Research Insights, 2: 2-6.

Jung-in, S. B., Jun, M. K. \& Shane, C. B. (2015). Students' Unethical Academic Behaviors: A SelfDetermination Theory Approachm, J. of Tourism and Hospitality Management, 3(2): 60-72.

Kalhori, Z. (2014). The Relationship between Teacher-student Rapport and Students Willingness to Cheat. Procedia - Social and Behavioral Sciences, 136: 153-158.

King, D. L. \& Case, C. J. (2014). E-Cheating : Incidence and Trends Among College Students. Issues in Information Systems, 15(I): 20-27.

Lin, C. H. S. \& Wen, L. Y. M. (2007). Academic dishonesty in higher education-a nationwide study in Taiwan. Higher Education, 54(1): 85-97.

Ma, Y., McCabe, D. L. \& Liu, R. (2013). Students' Academic Cheating in Chinese Universities: Prevalence, Influencing Factors, and Proposed Action. Journal of Academic Ethics, 11(3): 169184.

Muchai, J. (2014). An investigation into factors that contribute to cheating in examinations in Technical Institutions in Central Province, Kenya.

Mustapha, R., Hussin, Z., Siraj, S. \& Darusalam, G. (2016). Does Islamic religiosity influence the cheating intention among Malaysian Muslim students? A modified theory of planned behavior. International Journal of Academic Research in Business and Social Sciences, 6(12): 389-406.

Nora, W. L. Y. \& Zhang, K. C. (2010). Motives of cheating among secondary students: The role of selfefficacy and peer influence, 573-584. 
INTERNATIONAL JOURNAL OF ACADEMIC RESEARCH IN BUSINESS AND SOCIAL SCIENCES

Vol. 8, No. 11, Nov, 2018, E-ISSN: 2222-6990 @ 2018 HRMARS

Sarita \& Dahiya, R. (2015). Academic cheating among students: Pressure of parents and teachers. 1(10): 793-797.

Smith, M., Ghazali, N. \& Noor Minhad, S. F. (2007). Attitudes towards plagiarism among undergraduate accounting students: Malaysian evidence. Asian Review of Accounting, 15(2): 122-146. 